\title{
MEMOIRS
}

\author{
EGON SHARPE PEARSON
}

Emeritus Professor Egon Sharpe Pearson (ESP to many) died in June 1980 at the age of 83 . He had been an Honorary Member of the Institute since 1956. His death marks the end of an era in statistics since he was the famous son of a famous father, Karl Pearson, both of whom achieved Fellowship of the Royal Society. Karl was appointed Professor of Applied Mathematics at University College London in 1884 at the age of 27, retiring as Galton Professor of Eugenics and Head of the Department of Applied Statistics in 1933. His son, Egon, joined the latter department as Lecturer in 1921, retiring as Professor of Statistics in 1960 but remaining as an Honorary Research Fellow in the College until his death. Their joint service of 96 years, to the College and to the development of statistical methodology, is an achievement that must be unique in virtually any field of intellectual endeavour.

As a teacher ESP was a conmmanding figure, but modest in all he did and said with a very patient and thoughtful approach. He had a gift for handling data and deriving the appropriate mathematics to fit the problem posed by the data from first principles rather than the other way round. His lectures to first year undergraduates in the early post-war years covered an immense range of ground and still read well today. It was at the same 1946-48 period that the Institute recommended 'a more central and systematized treatment of statistics' and asked ESP to give two courses of evening lectures designed for members of the Institute. A series of thirty-five well attended lectures was given at University College in those years.

ESP made a number of important research contributions. He wrote in all some 128 scientific papers (although interestingly never wrote a textbook) of which some two thirds were published in Biometrika. This journal was founded by Karl in 1901 and later edited by ESP himself from 1933 to 1966. Anybody who has read that journal will know of its immense prestige in statistical circles, whilst those who have also written for it will be aware of the immense care ESP gave to all manuscripts received, and the efforts he made to turn an unacceptable manuscript into an acceptable paper if he felt that some real spark of statistical interest was embedded in the original manuscript.

Although so much of his work was, not unnaturally, published in Biometrika, some of his major contributions appeared elsewhere. There is a particular group of four papers published jointly with Jerzy Neyman, two in 1933 and two in 1936, that developed the theory of statistical tests, the principle of Type I and Type II errors with the concept of the power of a test, the concepts of suflicient statistics "and of the uniformly most powerful test. Neyman had first come to University College from Poland as a research student in $\mathbf{1 9 2 5}$ for a year. The collaboration with ESP continued by correspondence and occasional visits until 1934 when Neyman came to England on a more permanent basis. (The joint papers concerned were later republished in a collected edition in 1966 by Cambridge University Press.) Nobody who has read those papers can fail to fecl the intellectual excitement and satisfaction of the authors coming through, and the story of their collaboration over the years from 1926 to 1934 has been well described by ESP himself in the 1966 Fetschrift for J. Neyman.

There is one other great contribution that ESP made to statistics which deserves mention. In the Spring and Summer of 1931 ESP visited the United States giving lectures and seminars, and making a number of visits including one to the Bell Telephone Laboratories where quality control ideas were being developed. As a result, Walter Shewart of Bell was asked to give the 1932 University of London special lectures in statistics, whilst the British Standards Institution formed a small group which put together and published under ESP's name BS 600 on Statistical Methods in Industrial Standardization and Quality Control. The Royal Statistical Society in December 1932 asked ESP to read a paper on statistical methods in industry and two years later the Industrial and Agricultural Research Section was formed with its own journal (nowadays called Applied Statistics after the section was later split into two parts). ESP's role in all these moves was powerful and persuasive and he helped to start an important movement that persists today. 
ESP's career as a statistician touched many fields, ranging from pure research to applied methodology, from editing journals to the teaching of wide and disparate groups. To it all he brought a humility of approach and manner that was endearing to those who came into contact with him. His presidential address to the Royal Statistical Sociely in 1956 showed him at his best in demonstrating how common sense could be fruitfully applied to the analysis of data. Although my own personal interests in the applications of statistical methods diverged from his in later years, he was always ready to listen to a different viewpoint and a fresh approach. His loss is a grievous one, but he leaves behind him much that will be admired by the generations that follow.

P. G. MOORE

\section{ROBERT OSWALD BLYTH}

Robert Oswald Blyth, died on 9 September 1980, aged 97. He became a Fellow in 1913. He joined Scottish Amicable life Assurance Society in May 1905 having graduated as an M.A. at Glasgow University. His father Robert Blyth C.A., F.F.A. had been General Manager of that Office from 1891 to 1894 and then General Manager of the Union Bank of Scotland. Oswald Blyth qualified as a Fellow of the Faculty in 1909.

After war service on the HQ staff of the Heavy Artillery Training Centre at Winchester he returned to Scottish Amicable and after a spell in London was appointed Assistant Manager at Head Office, a position which he held until he decided to retire early on 31 December 1928.

In his retirement he pursued his love of ornithology and became a well-known authority on birds and their habits. He in fact kept a record every day for over 80 years of the species of bird he had seen that day. He remained in excellent health until close to the end of his long life and enjoyed a period of retirement of over 50 years. At the time of his death he was the oldest Fellow of both the Faculty and the Institute, having theen born on 18 May 1883. At the time of his death he was the senior Fellow of the Faculty by length of time qualified.

M. D. Paterson 